\title{
PERAN KOMUNITAS KETIMBANG NGEMIS PEKANBARU DALAM MENINGKATKAN KEPEDULIAN SOSIAL MASYARAKAT MELALUI MEDIA INSTAGRAM
}

\author{
Genny Gustina Sari ${ }^{1}$, Ismandianto ${ }^{2}$, Rasyida Darman ${ }^{3}$ \\ Jurusan Ilmu Komunikasi FISIP - Universitas Riau \\ Email : \\ 1 genny.gustina@lecturer.unri.ac.id \\ 2ismandianto@lecturer.unri.ac.id \\ 3rasyidadarman23061995@gmail.com
}

\begin{abstract}
Pekanbaru as the capital of Riau Province is inseparable from the problem of urban poverty which showed an increase of 0.22\% in the period September 2019 to September 2020. The number of beggars every year is increasingly significant. Social activities as a form of public concern by the Pekanbaru Rather than Ngemis Community which aim to inspire people in the city of Pekanbaru to work rather than beg. This activity was carried out, among others, to promote the "noble figure" as an inspirational figure displayed through their Instagram channel @ Ketimbang.Ngemis.Pekanbaru. this research using qualitative research methods and supported by the theory of technological determinism. The subjects in the study consisted of four people who were selected through a purposive technique. The technique of collecting data in this research is through deep interviews, observation, and documentation. The results of this study indicate that Instagram @ Ketimbang.Ngemis.Pekanbaru is able to attract the interest of the people of Pekanbaru to participate in social activities held by the community, especially as donors. But on the other hand, the content of messages and activities on the Instagram channel @ Ketimbang.Ngemis.Pekanbaru has not shown a significant impact on reducing the number of beggars in Pekanbaru City. Instead, the contents of these messages increase the creativity of beggars who try to attract public sympathy by imitating the "noble figure" published. community rather than begging Pekanbaru.
\end{abstract}

Keywords: Instagram, Social Concern, Beggars

\begin{abstract}
ABSTRAK
Pekanbaru sebagai ibukota Provinsi Riau tidak terlepas dari masalah kemiskinan perkotaan yang menunjukkan peningkatan sebesar $0.22 \%$ pada periode September 2019 ke September 2020. jumlah pengemis setiap tahunnya semakin signifikan. Kegiatan-kegiatan sosial sebagai bentuk kepedulian masyarakat oleh Komunitas Ketimbang Ngemis pekanbaru yang bertujuan memberikan inspirasi bagi masyarakat dikota Pekanbaru untuk bekerja daripada mengemis. Kegiatan ini dilakukan antara lain untuk mempromosikan "sosok mulia" sebagai sosok inspiratif yang ditampilkan melalui kanal instagram mereka @Ketimbang.Ngemis.Pekanbaru. Penelitian ini menggunakan metode penelitian kualitatif dan didukung dengan Teori Determinisme Teknologi. Subjek dalam penelitian terdiri dari empat orang yang dipilih melalui teknik purposive. Teknik pengumpulan data pada penelitian ini melalui wawancara medalam, observasi, dan dokumentasi. Hasil penelitian ini menunjukkan bahwa Instagram @Ketimbang.Ngemis.Pekanbaru mampu menarik minat masyarakat kota Pekanbaru untuk ikut berpartisipasi dalam kegiatan-kegiatan sosial yang diadakan komunitas tersebut khususnya sebagai donator melalui postingannya. Namun di sisi lain, isi pesan dan aktivitas di kanal instagram @Ketimbang.Ngemis.Pekanbaru belum menunjukkan dampak yang signifikan terhadap pengurangan jumlah pengemis di Kota Pekanbaru justru isi pesan tersebut meningkatkan kreativitas pengemis yang mencoba menarik simpati masyarakat dengan meniru "sosok mulia” yang dipublikasikan komunitas ketimbang ngemis Pekanbaru.
\end{abstract}


Kata Kunci : Instagram, Kepedulian Sosial, Pengemis

\section{PENDAHULUAN}

Kemunculan media sebagai suatu teknologi internet secara otomatis turut pula mempengaruhi perkembangan media sosial di masyarakat. Media sosial adalah media online yang mendukung interaksi sosial. Media sosial menggunakan teknologi berbasis web yang mengubah komunikasi menjadi dialog interaktif. Melalui media sosial setiap orang bisa membuat, menyunting, sekaligus mempublikasikan sendiri konten berita, promosi, artikel, foto, dan (Nurudin, 2007) dan (Nasrullah, 2016).

Instagram merupakan sebuah aplikasi khusus berbagi foto dengan fungsinya untuk mengunggah, mengambil foto, mengedit foto, menambahkan filter digital foto (efek foto), memberi komentar pada foto, dan membagikan foto keberbagai layanan jejaring sosial lainnya, bahkan dalam instagram seseorang dapat mengabadikan peristiwa-peristiwa menarik dan beharga dirinya account instagram tersebut, lalu dibagikan kepada sesame pengguna instagram. Saat ini, Instagram merupakan platform yang paling banyak digunakan masyarakat Indonesia yaitu sebanyak 79\% dari jumlah populasi atau berada di uritan ke-4 (https://andi.link/hootsuite-we-are-social-indonesian-digital-report-2020/)

Instagram merupakan ruang komunikasi terbuka bagi semua masyarakat yang termasuk media dalam komunikasi massa, selain digunakan untuk memperbarui status tentang kehidupan pribadi, instagram juga digunakan sebagai alat untuk menyampaikan berita. karena saat ini instagram menjadi salah satu sarana mendapatkan berita yang cepat bagi setiap masyarakat yang aktif didunia maya (Atmoko, 2012), dan (Enterprise, 2012). Banyak hal yang bisa ditiru, dicontoh atau sekedar ditonton di kanal Instagram tersebut khususnya bagi masyarakat yang tinggal di kota-kota besar seperti Pekanbaru.

Pada September 2020 terjadi peningkatan jumlah penduduk miskin di Kota Pekanbaru sebesar 0,22 \% atau sekitar 7.30 ribu jika dibandingkan September 2019. Berdasarkan keterangan Ketua Badan Pusat Statsitik (BPS) Provinsi Riau yaitu Misfarudin menyatakan kenaikan jumlah penduduk miskin ini disebabkan oleh peningkatan harga sembako dan dampak dari pandemik COVID-19. Pada bulan Agustus 2020 terdata jumlah penduduk Kota Pekanbaru yang menjadi pengangguran sebesar 35,40 \% ${ }^{1}$

Salah satu informasi yang cukup menarik perhatian masyarakat yang disampaikan di Instagram selama pandemic Covid-19 adalah aktivitas kepedulian sosial. Hal ini tentunya bisa dimaklumi, mengingat dampak bencana Covid-19 tidak bisa dielakkan dan mengenai hampir seluruh sisi kehidupan termasuk ekonomi. Selama masa pandemic Covid-19 saja penulis mengamati terjadi peningkatan jumlah pengemis di 5 titik lampu lalu lintas di Kota Pekanbaru yang didominasi oleh pengemis usia produktif (riset tanggal 5 s/d 10 Agustus 2020 di Jalan Sudirman, Simp SKA, Pasar Arengka, Di Depan kantor POLDA Riau dan di Depan Rumah Gubernur Riau.)

Penelitian yang dilakukan oleh Alfina Ester Rositawati dengan judul korelasi penggunaan instagram dengan perilaku menolong oleh mahasiswa (Rositawati, 2018) menunjukkan bahwa pengaruh terbesar penggunaan Instagram @ketimbang.ngemis.solo oleh mahasiswa adalah terhadap aspek konatif (Perilaku menolong) yaitu 0,860 (Rositawati, 2018). Kegiatan sosial yang dilakukan komunitas Ketimbang Ngemis Bengkulu menunjukkan tahapan pemberdayaan masyarakat mulai dari persiapan, pelaksanaan dan evaluasi. Program pemberdayaan yang dilakukan oleh 'Pengungsi ngemis bengkulu' ini sangat bermanfaat untuk meningkatkan kebiasaan dan menciptakan kesadaran terhadap sesama manusia (Utamami, 2019). Penelitian Yusmawati mengenai makna ambiguitas pesan pemberdayaan masyarakat

\footnotetext{
${ }^{1}$ https://www.gatra.com/detail/news/503852/ekonomi/jumlah-penduduk-miskin-di-riau-melonjak-pada2020\#: :text=Kasim\%20kota\%20Pekanbaru.(GATRA\%2FKurnia).,periode\%20yang\%20sama\%20tahun\%202019. (Diakses Tanggal 14 April 2021)
} 
yang melihat kampanye sosial Ketimbang Ngemis di media sosial menunjukkan bahwa makna denotatif para lansia identik dengan aktivitas meminta-minta sedangkan makna konotatif menunjukkan aktivitas sosial yang dilakukan akan menimbulkan perilaku pengemis yang malas, tidak berdaya dan tidak mandiri (Yusmawati, 2018).

Melalui kanal Instagramnya, komunitas Ketimbang Ngemis Pekanbaru aktif melakukan kegiatan sosial khususnya selama masa pandemic Covid-19 ini. Tujuan lain kegiatan dan komunitas ini didirikan tentunya untuk mengajarkan sekaligus memotivasi dan menginspirasi masyarakat Kota Pekanbaru untuk menghargai "sosok mulia" yang didefenisikan sebagai orangorang dengan kondisi ekonomi memprihatinkan namun memilih bekerja ketimbang ngemis sebagai sosok inspiratif yang akan diangkat dan menjadi subjek dalam kegiatan-kegiatan mereka.

Komunitas merupakan suatu kelompok yang didalam setiap anggotanya disatukan oleh persamaan visi dan misi serta tujuan. Komunitas sosial adalah komunitas non profit yang didalamnya setiap anggota merumuskan visi, misi, serta tujuan dan merealisasikan visi, misi, serta tujuan tersebut kedalam tindakan nyata. Dengan tujuan tersebut, komunitas sosial pada umumnya bergerak untuk meningkatkan kesadaran sosial pada masyarakat dengan menggerakkan sektor pendidikan, sejarah, budaya dan lain-lain (Ardianto, 2007). Mempelajari komunitas sosial tentunya tidak terlepas dari perkembangan komunitas sosial yang ada. Salah satu contoh komunitas sosial yang menjadi objek penelitian ini adalah @Ketimbang.Ngemis.Pekanbaru. Kegiatan sosial yang dilakukan komunitas ketimbang ngemis Pekanbaru umumnya bersifat memberi bantuan, dengan memiliki kriteria yang dibuat oleh pengurus komunitas sosial tersebut. Kegiatan yang dilakukan oleh komunitas ini selain memberikan bantuan kepada target mereka, membantu para target berjualan barang dagangannya serta membeli barang dagangan para target tersebut. Aktivitas ini kemudian di share dan diposting di akun intagram dengan tujuan menimbulkan kesadaran masyarakat sekaligus menarik minat masyarakat untuk melakukan hal yang serupa.

Hal ini kemudian menarik minat penulis untuk meneliti bagaimana peningkatan kepedulian sosial di Kota Pekanbaru melalui aktivitas komunitas ketimbang ngemis Pekanbaru di akun instagram mereka. Komunitas yang awalnya diprakarsai oleh anak muda yang bernama Risky dari Yogyakarta ini, mengusung tag line Say No to "mengemis: belilah walaupun tidak membutuhkan". Pada awalnya ia hanya memposting di akun instagram pribadinya karena muncul perasaan terharu melihat perjuangan dari nenek dan kakek dalam menjalani hidup. Kemudian dampak dari postingannya tersebut banyak netizen yang antusias dan memberikan respon positif. Hingga risky membuat akun instagram @ketimbang.ngemis agar makin banyak orang yang sadar untuk membantu para lansia dikota masing-masing.

Menyebar luasnya akun instagram @Ketimbang.Ngemis regional Yogyakarta membuat akun ini tersebar diseluruh Indonesia hingga terbentuk juga komunitas sosial ini di Kota Pekanbaru dengan nama @Ketimbang.Ngemis.Pekanbaru. Saat ini jumlah followers @Ketimbang.Ngemis.Pekanbaru sebanyak 8628 dengan jumlah postingan 363 postingan. Komunitas ini berdiri pada tanggal 31 januari 2016 dengan anggota kurang lebih berjumlah 39 orang yang diketuai oleh Denny Rimadana.

\section{Gambar I Screenshoot Akun Instagram @ ketimbang.ngemis.pekanbaru}

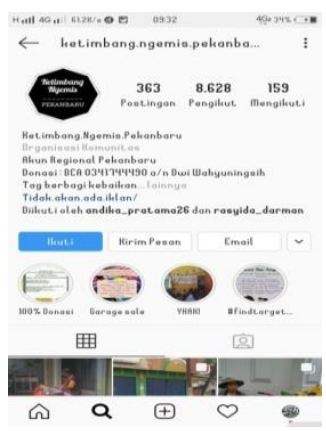

Sumber:@ketimbang.ngemis.pekanbaru 
Informasi orang-orang yang membutuhkan pertolongan biasanya didapatkan dari orangorang yang men-tag keakun @Ketimbang.Ngemis.Pekanbaru, lewat DM (Draft message) instagramnya, atau dari anggota yang menemukan orang yang masuk kriteria untuk dibantu lalu difoto dan ditanya-tanya latar belakanganya. Salah satu yang menjadi target yang pernah diberi bantuan komunitas ini adalah seorang lelaki paruh baya bernama Albert berusia 63 tahun yang bekerja mengumpulkan barang bekas. Beliau hidup sebatang kara dan tinggal di gubuk yang sangat tidak layak untuk ditempati, namun beliau tidak ingin meminta balas kasihan orang dengan kondisi yang ia hadapi dan memilih untuk tekun bekerja meski hasil yang ia dapatkan tidak seberapa untuk kebutuhan hidupnya. beliau mendapatkan bantuan dari komunitas Ketimbang Ngemis Pekanbaru berupa sembako dan uang tunai senilai Rp.2.500.000,-

Komunitas Ketimbang Ngemis Pekanbaru ini memiliki prosedur dalam hal memberikan bantuan. Setelah mendapatkan informasi terlebih dahulu tim akan melakukan survey ketempat kerja, tempat tinggalnya, serta mencari informasi kepada tetangga sekitar lingkungan tempat tinggal target. Hal ini dilakukan agar nantinya pemberian bantuan tidak salah sasaran. Untuk ikut turut serta membantu atau menyumbangkan dana biasanya dari transfer ke rekening yang sudah tersedia atau menghubungi langsung anggota komunitas ini. Sumber bantuan didapat dari donator tetap yang terdiri dari beberapa perusahaan menengah dan individu serta donator tidak tetap yang sifatnya accidental yaitu hanya memberi bantuan saat komunitas telah menemukan target dan menentukan waktu untuk mendistribusikan bantuan.

Penelitian ini menggunakan Teori determinisme teknologi. Teori determinasi teknologi diartikan sebagai bahwa setiap kejadian atau tindakan yang dilakukan manusia itu akibat pengaruh dari perkembangan teknologi. Perkembangan teknologi tersebut tidak jarang membuat manusia bertindak diluar kemauan sendiri. Pada awalnya, manusialah yang membuat teknologi, tetapi lambat laun teknologilah yang justru mempengaruhi setiap apa yang dilakukan manusia (McQuail, 2005). Zaman dahulu belum ada handphone dan internet. Tanpa ada dua alat komunikasi itu keadaan manusia biasa saja. Tetapi sekarang dengan ketergantungan pada dua perangkat itu manusia jadi sangat tergantung. Teori Determinisme Teknologi pertama kali dikemukakan oleh Marshall McLuhan di tahun 1962 melalui tulisannya yang berjudul The Guttenberg Galaxy: The Making of Typographic Man dengan pokok gagasan dari teori ini adalah bahwa pola kehidupan masyarakat manusia, khususnya aspek interaksi sosial diantara mereka, ditentukan oleh perkembangan dan jenis teknologi yang dikonsumsi oleh masyarakat itu sendiri (McLuhan. 1994:108). McLuhan berpendapat bahwa media merupakan faktor utama yang paling memperngaruhi hal lainnya. Secara umum, teori determinisme teknologi ini berusaha menjelaskan bagaimana sebuah teknologi terutama media sangat berpengaruh dalam menentukan bagaimana individu dalam masyarakat memikirkan, merasakan dan melakukan suatu tindakan tertentu (Febriana \& others, 2018).

Teknologi saat ini telah menjadi bagian dari kehidupan sehari-hari (everyday life) masyarakat tidak hanya dikota-kota besar namun hingga kepelosok daerah. Jika kita melihat bagaimana sejarah munculnya akun dan komunittas Ketimbang Ngemis terjadi karena efek media sosial yang menjadi bagian penting dari representasi dirimasyarakat saat ini. Bagaimana jiwa sosial manusia digugah lewat postingan kegiatan sosial yang dulunya dianggap tabu untuk diumbar karena anggapan riya (pamer) dalam agama Islam yang mengganjar pelakunya dengan dosa besar. Namun perkembangan teknologi nyatanya dimanfaatkan untuk membantu sesame lewat postingan-postingan yang dikomodifikasi sedemikian rupa unttuk menyentuh sisi kemanusian masyarakat pengguna media tersebut.

Focus dan tujuan penelitian ini sebenarnya melihat bagaimana upaya komunitas Ketimbang Ngemis Pekanbaru meningkatkan kepedulian dan kesadaran masyarakat tentang fenomena pengemis di kota besar melalui media social Instagram @ketimbang.ngemis.pekanbaru dengan menghadirkan "sosok mulia" sebagai tokoh inspiratif yang memilih bekerja ketimbang mengemis. Pada akhinya, penelitian ini berusaha melihat dan menganalisa kelemahan dari program yang dilaksanakan komunitas Ketimbang Ngemis Pekanbaru dan solusi yang mungkin bisa diberikan. 
Metode yang digunakan dalam penelitian ini adalah metode deskriptif kualitatif. Menurut Kirk dan Milter (Moleong, 2005) mendefinisikan bahwa penelitian kualitatif adalah tradisi tertentu dalam ilmu pengetahuan sosial yang secara fundamental bergantung dari pengamatan pada manusia baik dalam wawasannya maupun peristilahannya (Bungin, 2007).

Teknik pengumpulan data dalam penelitian ini selain menggunakan wawancara juga penulis melakukan observasi dengan cara ikut serta dalam beberapa aktivitas social mereka sejak Januari hingga Maret 2020. Namun sejak diberlakukannya pembatasan social terkait pandemik, maka komunitas ketimbang ngemis juga menghentikan sementara aktivitas social mereka. Selama itu penulis lebih banyak melakukan wawancara atau mengikuti anggota komunitas yang ingin melakukan aktivitas social secara individu.

Informan dalam penelitian ini berjumlah 6 orang dari total anggota komunitas sebanyak 33 orang dengan teknik penentuan menggunakan purposive sampling dimana kriteria yang penulis tentukan adalah pengurus aktif kegiatan di komunitas Ketimbang Ngemis Pekanbaru yang aktif mengikuti kegiatan komunitas dari awal berdirinya komunitas tersebut.

\section{HASIL DAN PEMBAHASAN}

Komunitas Ketimbang Ngemis Pekanbaru bertujuan untuk memberikan inspirasi bagi masyarakat di kota Pekanbaru dan anak muda agar giat bekerja supaya tidak menjadi sia-sia ketika di usia senja nantinya. Sosok mulia yang akan diberi banguan dissebut sebagai "taerget" hal ini bukannya tanpa alasan, karena komunitas ini terllebih dahulu akan melakukan survey untuk menentuka kelayakan target menjadi "sosok mulia" yang akan diangkat sebagai sosok inspiratif nantinya. Yang menjadi focus komunitas ini adalah para Lansia yang masih produktif bekerja.

\section{Tabel I. Data Jumlah orang-orang yang dapat bantuan oleh Komunitas @Ketimbang.Ngemis.Pekanbaru}

\begin{tabular}{|l|l|l|}
\hline No & Tahun & $\begin{array}{l}\text { Jumlah yang dibantu oleh } \\
\text { komunitas } \\
\text { @Ketimbang.Ngemis.Pekanbaru }\end{array}$ \\
\hline 1. & 2017 & 32 Orang \\
\hline 2. & 2018 & 36 Orang \\
\hline 3. & 2019 & 42 Orang \\
\hline
\end{tabular}

Sumber: Data Arsip Komunitas @Ketimbang.Ngemis.Pekanbaru (2019)

Dapat dilihat dari tabel diatas, peningkatan jumlah orang yang kurang mampu masih banyak dan yang dapat dibantu oleh komunitas Ketimmbang Ngemis Pekanbaru mengalami peningkatan yang cukup signifikan. Selain karena meningkatnya jumlah angka kemiskinan di Kota pekanbaru, peningkatan jumlah target yang mendapat bantuan juga terjadi karena semakin banyaknya masyarakat Kota pekanbaru yang ikut serta memberi bantuan baik tenaga maupun materu (Hasil wawancara dengan Denny, 7 Mei 2020) Adapun jenis bantuan yang diberikan oleh komunitas ini berupa uang tunai, sembako dan baju layak pakai, lama waktu pemberian bantuan ini tidak ditetapkan karena ini diberikan hanya satu kali untuk setiap orang yang menerima bantuan.

Dalam menjalankan fungsi komunikasi, komunitas Ketimbang Ngemis Pekanbaru berkewajiban untuk memberikan informasi dan memberikan jawaban atas kepentingan serta keingintahuan public atau followers mengenai apa-apa saja terhadap komunitas terutama sosok mulia. Kedua, menggunakan media sosial sebagai sarana promosi. Dalam fungsi ini, komunitas Ketimbang Ngemis Pekanbaru dapat menjangkau publik secara lebih luas, dengan adanya fiturfitur instagram yang dimanfaatkan seperti, comment, efek foto, arroba, dan judul foto yang dapat memberikan isi pesan dari produk yang ditawarkan sehingga memiliki konten yang efektif dan efesian. Penggunaan instagram itu sendiri tentu menjadi alasan tertentu bagi komunitas Ketimbang Ngemis Pekanbaru agar lebih mudah melakukan kegiatan sosial melalui media sosial instagram tanpa menggunakan biaya dan efesien. Hal ini dapat dilihat dari tingkat kepedulian followers mengalami peningkatan yang baik. 
Terdapat fitur-fitur yang mampu mendukung proses pemanfaatan instagram sebagai media untuk mempromosikan sosok mulia, terdapat keterkaitan antara fitur-fitur yang dimanfaatakan dengan proses pemanfaatan media yang tepat untuk komunitas Ketimbang Ngemis Pekanbaru fitur yang dimanfaatkan oleh komunitas kepedulian sosial peneliti analisa lebih mendalam sehingga muncul keterkaitan-keterkaitan tersebut. Pesan merupakan sesuatu yang disampaikan dari komunikator atau pengirim kepada komunikan atau khalayak. Pesan dapat disampaikan secara tatap muka ataupun melalui media komunikasi. Untuk dapat dimengerti dengan baik oleh masyarakat, pesan yang disampaikan harus dapat dimengerti dan dicerna dengan baik oleh masyarakat sebagai sasarannya.

"karena sejarahnya kegiatan ini besar lewat instgram oleh karena itu kami juga mengikuti instruksi atau menyeragamkan dengan media pusat di Jogya yaitu Instagram, saya sendiri merasa infromasi yang saya upload di Ig itulah yang nantunya tidak hanya sebagai sumber informasi tetapi juga menjadi daya Tarik agar orang-orang mau dan bersedia membantu kegiatan dan program kami" (wawancara dengan Singgih Aidil, Admin IG @Ketimbang.Ngemis.Pekanbaru)

Dalam pengelolaan pesan komunikasi yang dilakukan oleh komunitas Ketimbang Ngemis Pekanbaru memliki tujuan yang mempunyai makna bagi penerimanya dan harus sesuai dengan sistem nilai penerima. Pada umunya orang memilih informasi yang singkat, padat, dan jelas. Pesan yang panjang lebar juga membuat orang bosan untuk membacanya.

Komunitas ini menyususn dan menentukan informasi apa yang layak untuk disampaikan atau tidak dengan melakukan rapat direksi yang dilakukan minimal 4x dalam setiap kegiatan. Pemilihan pesan yang dikemas oleh komunitas Ketimbang Ngemis Pekanbaru juga mempengaruhi Followers. Hal ini tidak terlepas dari kemampuan tim dalam mengolah pesan-pesan social yang disampaikan kepada followers.

"sebelum kami mengupload informasi kepada followers, tim akan melakukan rapat minimal $4 x$ perkegiatan. $1 x$ sebelum kegiatan untuk menentukan siapa yang survey, tema apa yang akan ditonjolkan, siapa yang akan ditargetkan sebagai donator dan sebagainya. Rapat ke-2 kami akan mengolah data survey dan menerukan ke Tindakan selanjutnya, rapat ke-3 biasanya kami lakukan sesaat sebelum kegiatan dilaksanakan yang merangkum bagaimana teknis peliputan, teknis dilapangan serta siapa saja yang bertugas dilapangan, rapat tterakhir kami lakukan setelah kegiatan untuk mengevaluasi kelebihan dan kekurangan kegiatan tersebut" (wawancara Fajri Ramadhan, Penanggung Jawab Kegiatan).

Evaluasi dalam menentukan sebuah keberhasilan sangat penting dan mempengaruhi dalam kegiatan yang dilakukan oleh komunitas Keetimbang Ngemis Pekanbaru dalam melaksanakan fungsinya sebagai penyalur informasi kepada followers tentang sosok mulia yang menjadi target dalam kegiatan kepedulian sosial komunitas. Untuk menentukan aspek yang akan dievaluasi oleh komunitas adalah menunjukkan bahwa kegiatan yang dilakukan oleh komunitas benar adalah kegiatan sosial yang memiliki manfaat bagi target yang telah ditentukan oleh komunitas melalui postingan diakun instgram komunitas Ketimbang Ngemis Pekanbaru.

Dari hasil analisa penulis, penulis mendapati salah satu pemanfaataan media sosial untuk berkomunikasi dengan publik atau para followers adalah @Ketimbang.Ngemis. Pekanbaru berkewajiban untuk memberikan informasi dan memberi jawaban atas kepentingan serta keinginan publik/Follower mengenai sosok mulia. Pemanfaatan ini dilakukan agar dapat memperkenalkan sosok mulia ke khalayak, dalam hal ini Instagram. Sehingga khalayak ataupun followers di Kota Pekanbaru tersebut dapat mengetahui adanya keberadaan sosok mulia dan komunitas Ketimbang Ngemis Pekanbaru melalui instagram.

"selain sebagai media promosi keegiatan dan komunitas ini, kami tentunya mengharapkan kegiatan ini bisa viral tidak hanya di Pekanbaru saja tetapi bisa di Indonesia. Kan sekarang gampang ya kak buat jadi viraal.. orang-orang pasti punya Instagram dan pasti liatin Instagram setiap hari..itulah yang kami manfaatkan kak. menyentuh sisi kemanusiaan lewat konten dan unggahan kami di media social" (wawancara dengan DDenny Pramana, Ketua Komunitas Ketimbang Ngemis Pekanbaru).

Dalam pemanfaatan media sosial instagram sebagai media komunikasi dengan memperhatikan caption yang menarik dan menyentuh di hati followers, poin-poin yang 
diperhatikan yakni bahasa yang digunakan santai seperti saat berbicara dengan teman sendiri. Tidak terlalu panjang lebar tetapi singkat dan bemakna, terpenting mencantumkan nama, usia, pekerjaan, jualan, dan waktu jualan, jumlah penghasilan, jumlah tanggungan serta menceritakan kisah yang dialami oleh sosok mulia sendiri. Setelah caption, pemilihan gambar, gambar yang digunakan harus sesuai, maksudnya adalah foto harus sudah bisa menceritakan keadaan dalam artian memilih foto dimana foto tersebut jelas dan tidak kabur. Dengan di dukung caption maka kedua hal tersebut sudah bisa menarik empati dari masyarakat. Setiap unggahan foto dari komunitas Ketimbang Ngemis Pekanbaru tidak sembarangan, namum menggunggah foto saat sore-malam. Hal ini disiasati agar banyak followers yang melihat postingan yang ada diinstagram tersebut. Tidak terlepas dari fitur-fitur instagram sendiri yakni menggunakan hastag, arroba, captions dan lain sebagainya. Didukung dengan informasi kegiatan dan laporan kegiatan komunitas.

Penulis melihat pemanfaatan instagram sangat membantu dalam hal kepedulian sosial. Media sosial instagram mampu berkomunikasi dengan publik atau follower secara langsung. Dalam fungsi komunikasi itu, tim ketimbang Ngemis Pekanbaru memberikan informasi dan memberi jawaban atas kepentingan serata keingintahuan followers mengenai sosok mulia dari komunitas. Penulis melihat, Komunitas ini memanfaatkan ketergantungan followers dalam menggunakan media social sebbagai bentuk kebutuhan masyarakat. Masyarakat dan internet menjadi satu kesatuan yang tidak bissa dipisahkan. Sebuah berita bisa dengan begitu cepat menjadi viral dihari ini dan dilupakan diesok hari karena telah digantikan berita baru.

Namun satu hal yang penulis lihat luput dari perhatian komunittas ketimbang Ngemis Pekanbaru ini adalah bahwa hamper Sebagian besar pengguna media social dalam hal ini Instagram adalah ppara penonton pasif. Media social dijadikan sebagai media hiburan yang digunakan untuk menghibur diri, menunjukkan eksistensi dan mencari pengakuan ketimbang sebagai ajang untuk bertindak secara aktif. Hal ini bisa dilihat dari seberapa besar terpaan informasi terhadap responb para followers itu sendiri. Ditambah dengan banyaknya kajiankajian yang lebih dalam dan lebih luas menunjukkan fungsi dan peran media social dalam kehidupan sehari-hari.

Pertama, komunitas ketimbang Ngemis Pekanbaru dalam menentukan target terlebih dahulu memilih benar-orang sosok mulia yang akan menjadi target dari komunitas itu melalui survey apakah tepat sasaran. Sehingga pesan yang disampaikan akan disesuaikan dengan latarbelakang mereka masing-masing dengan tujuan agar pesan dapat dengan mudah dipahami. Bahasa yang digunakan memliki ragam yang berbeda pada setiap isi pesan yang akan disampaikan.

“.. saat survey, saya dan tim biasanya akan berkeliling kota Pekanbaru selama 2-3 hhari dari hhasil yang didapatkan kemudian akan dirapatkan siapa saja yang akan diangkat menjadi Sosok Mulia dan siapa yang tidak. Ini proses yang tidak mudah tentunya mengingat banyaknya calon sosok mulia yang bisa dianggkaat namun dana dan tenaga kami terbatas" (Wawancara dengan Wahyu Rusiana, Tim Survey).

Kedua, komunitas akan menentukan isi pesan yang disampaikan berdasarkan kenyataan dilapangan sehingga masyarakat dan followers tertarik untuk membantu sosok mulia tersebut. Tanpa ada rasa bimbang dan rasa ketidak jujuran dari komunitas. Isi pesan tersebut dibuat sebaik mungkin sehingga semua kalangan yang melihat mudah memahami dan memaknai pesan. Ketiga, Gaya penyampaian pesan dilakukan oleh komunitas Ketimbang Ngemis Pekanbaru adalah gaya bahasa yang mudah dipahami oleh followers sehingga penyampaian pesan berlangsung secara aktif, efektif, komunikatif dan menyenangkan. Melalui konsep ini komunitas menyampaikan secara detail dan sangat mudah melalui pesan nonverbal kepada followersnya.

"dalam Menyusun pesan, kami berusaha agar Bahasa yang digunakan bisa dengan mudah diterima oleh kaum remaja dan sekaligu orang dewasa pada saat yang bersamaa. Hal ini bertujuan agar informasi yang kami berikan tidak membedakan antar usia. Karena tujuan kami ingin memperlihatkan ini loh.. Gerakan social yang dilakukan anak muda bukan untuk anak muda..."(wawancara dengan Serly Rahmadaniama). 
Kegiatan evaluasi yang dilakukan oleh komunitas Ketimbang Ngemis Pekanbaru ini menjadi salah satu bagian dari hasil kegiatan yang dilakukan oleh komunitas tersebut dimana hasil akhir ini sangat mempengaruhi bagaimana proses yang sudah dilakukan oleh komunitas dalam memberikan distribusi bantuan kepada sosok mulia yang menjadi target dalam kegiatan sosial. Agar kegiatan evaluasi tersebut dapat dilakukan dengan baik maka komunitas perlu sebuah rancangan yang dibutuhkan untuk diberitahukan kepada semua donatur dan masyarakat khususnya followers sehingga mendapatkan hasil akhir yang baik. Perlunya mengumpulakn semua data dari target yang dibutuhkan sesuai dengan rancangan awal pada kegiatan social Ketimbang Ngemis pekanbaru agar dipertanggung jawabkan.

Setelah proses evaluasi berhasil dilaksanakan maka para anggota komunitas memberikan laporan kemedia sosial untuk menujukkan keberhasilan dari komunitas dalam melakukan kegiatan sosial dan diberikan kepada pihak yang berkepentingan seperti donatur tetap pada komunitas. Dengan hasil dokumentasi berupa foto dan video serta pesan dan tulisan yang baik. Intinya, komunitas akan memastikan terlebih dahulu keberhasilan sebuah kegiatan baru kemudian mengunggah di media social @Ketimbang.Ngemis.Pekanbaru.

Secara garis besar, penelitian ini menunjukkan bahwa aktivitas dan kegiatan yang dilakukan oleh komunitas ini berhasil menarik minat masyarakat Kota Pekanbaru untuk membantu menjadi donator melalui isi pesan yang mampu merepresentasikan ketidakberdayaan sekaligus kemuliaan "sosok mulia" di akun instagram mereka. Namun di sisi lain, aktivitas komunitas ini yang kemudian di posting di Intagram justru berperan sebagai pisau bermata dua. Penulis menemukan dalam 2 bulan terakhir bahwa kreativitas pengemis di Kota Pekanbaru mengalami peningkatan. Penulis melihat pengemis yang meminta-minta semakin berkurang digantikan sosok-sosok yang menduplikasi aktivitas "sosok mulia" agar menarik simpati dan empati masyarakat diantaranya, ada yang kemudian bermodalkan kemoceng menawarkan diri membersihkan kaca mobil, ada yang berjualan makanan dan tissue, penjual koran, pemulung dan sebagainya. Saat fenomena ini penulis konfirmasikan pada ketua Komunitas Ketimbang Ngemis Pekanbaru untuk mengetahui bagaimana solusi atau langkah konkrit untuk mengatasi masalah ini, namun dari pihak komunitas juga mengeluhkan fenomena yang sama yang tidak hanya terjadi di kota Pekanbaru tetapi hamper disemua kota-kota besar.

"nah... itu dia masalah baru kak, memang banyak respon positif untuk kegiatan-kegiatan social semacam ini tapi pengemis-pengemis itu jadi punya banyak akal untuk pura-pura meniru sosok mulia kak... kekuatan kita selama ini sebenarnya di survey tapi itu juga belakangan udah ngga efektif.. ngga hanya dipekanbaru kak, di Jogja dan kota-kota besar lainnya juga gitu kak.." wawancara dengan Denny Pramana, Ketua Komunitas Ketimbang Ngemis Pekanbaru).

Pada akhirnya kita bisa melihat bahwa konten-konten kebajikan yang pada mulanya bertujuan untuk mengugah solidaritas dan kepedulian masyarakat lewat media social malah berakhir dengan sebuah masalah baru. Munculnya sosok-sosok mulia yang baru membuat jumlah pengemis menurun namun jumlah masyarakat "memprihatinkan" semakin meningkat. Para pengemis yang bertransformasi menjadi sosok mulia dianggap jauh lebih bisa menarik perhatian masyarakat untuk mendonorkan uangnya. Sebuah lingkaran setan baru telah dimulai, strategi baru tentunya harus segera dirumuskan oleh komunitas Ketimbang Ngemis Pekanbaru dan komunitasgerakan-gerakan social lainnya.

\section{KESIMPULAN}

Berdasarkan pembahasan dari data penelitian yang penulis peroleh, maka dapat disimpulkan beberapa hal sebagai berikut:

1. Pesan yang dikemas oleh komunitas Ketimbang Ngemis Pekanbaru dalam melakukan kegiatan sosial yaitu dengan mengajak followers untuk melakukan kepedulian sosial terhadap sosok mulia. Gaya penyampaian pesan dalam kegiatan ini disesuaikan dengan bahasa yang lebih dimengerti oleh masyarakat dan khususnya followers sehingga pesan yang dikemas tersampaikan menjadi lebih mudah untuk dipahami dan kegiatan berjalan dengan aktif, efektif, komunikatif, dan menyenangkan

2. Evaluasi yang dilakukan komunitas sangat memberikan efek kepada para followers dan para donatur dalam melakukan kegiatan sosial kepada sosok mulia. Evaluasi ini dibuat 
oleh semua anggota komunitas dan ditentukan sebuah keberhasilan kegiatan yang mereka laksanakan. Evaluasi ini dilakukan dengan cara menyusun hasil akhir dari kegiatan komunitas kepada sosok mulia yang di sampaikan melalui insgtagram komunitas@Ketimbang.Ngemis.Pekanbaru.

3. Aktivitas komunitas ketimbang ngemis mampu menarik minat masyarakat Kota Pekanbaru untuk berdonasi namun tidak mengurangi jumlah pengemis di Kota Pekanbaru justru terlihat peningkatan pengemis yang menduplikasi kegiatan dan aktivitas sosok mulia.

\section{DAFTAR PUSTAKA}

Ardianto, E. (2007). Komunikasi Massa. Simbiosa Rekatama Media.

Atmoko, B. D. (2012). Instagram Handbook. Media Kita.

Bungin, B. (2007). Penelitian Kualitatif: Komunikasi, Ekonomi, Kebijakan Publik, dan Ilmu Sosial (Kedua). Kencana.

Enterprise, J. (2012). Instagram untuk fotografi digital dan bisnis kreatif. PT. Elex Media Komputindo.

Febriana, A. I. D., \& others. (2018). Determinasi Teknologi Komunikasi dan Tutupnya Media Sosial Path. LONTAR: Jurnal Ilmu Komunikasi, 6(2), 86-95. https://doi.org/10.30656/lontar.v6i2.948

McQuail, D. (2005). Teori Komunikasi Massa (kedua). Kencana Prenada Media Group.

Moleong, L. J. (2005). Metode penelitian kualitatif edisi revisi. Remaja Rosdakarya.

Nasrullah, R. (2016). Media Sosial Perspektif Komunikasi, Budaya, dan Sosioteknologi. Simbiosa Rekatama Media.

Nurudin. (2007). Pengantar Komunikasi Massa. Raja Grafindo Persada.

Rositawati, A. E. (2018). Korelasi Penggunaan Instagram dengan Perilaku Menolong oleh Mahasiswa (Studi Korelasi Penggunaan akun Instagram@ ketimbang.ngemis. soloo dengan Perilaku Menolong Mahasiswa Fakultas Ilmu Sosial Ilmu Politik Universitas Sebelas Maret Surakarta Angkatan 2012. Jurnal Komunikasi Massa, 1.

Utamami, Dwi Fitri. Ilham dan Sofino. (2019). Penggunaan Media Sosial Dalam Memberdayakan Masyarakat Miskin di Kota Bengkulu; (Studi Kasus Pada Lembaga Swadaya Masyarakat "Ketimbang Ngemis Bengkulu"). Journal of Lifelong Leraning Vol. 2 No.1.: 7-12

Yusmawati \& Restiawan Permana. (2019). Makna Ambiguitas Pesan Pemberdayaan Masyarakat (Studi Kasus: Kampanye Sosial "Ketimbang Ngemis" di Media Sosial). Jurnal Lugas Volume 2 No 2, 51-58. 